\title{
Morphogenetic effects of Congo red on hyphal growth and cell wall development of the fungus Saprolegnia monoica
}

\author{
Patrice Nodet, ANDré Capellano and Michel FèVre* \\ Laboratoire de Biologie Cellulaire Fongique, UMR CNRS 106, Université Claude Bernard Lyon 1, Bât. 405, \\ 43 Boulevard du 11 Novembre 1918, 69622 Villeurbanne Cedex, France
}

(Received 11 October 1989; accepted 18 October 1989)

\begin{abstract}
Cultures of Saprolegnia monoica were treated with Congo red, a dye which prevents glycan microfibril assembly. In the presence of the dye, the fungus developed cell wall thickenings and exhibited aberrant hyphal tips which expanded into spherical swellings. In the thickened cell walls, cellulose was produced as short microfibrils or amorphous material. These morphological anomalies were accompanied by changes in the localization of glucose incorporation into the cell wall which was not limited to the hyphal tips. Congo red uncouples the polymerization and crystallization of cellulose into normal microfibrils and it is suggested that the regular assembly of glucan chains into microfibrils is needed for normal hyphal morphogenesis.
\end{abstract}

\section{Introduction}

The general organization of hyphal cell walls comprises an inner layer of microfibrillar polysaccharides overlaid by an outer layer of amorphous polysaccharides (Burnett, 1979). In Saprolegnia monoica, as in other Oomycetes, these polysaccharides are, respectively, cellulose and $\beta$-1,3-/ $\beta$-1,6-glucans (Sietsma, 1969; Burnett, 1979).

Hyphal morphogenesis is closely related to cell wall synthesis and cell wall polysaccharide composition. Several inhibitors and paramorphogens which induce abnormal hyphal morphogenesis modify cell wall architecture and polysaccharide composition (Burnett, 1979; Fèvre \& Rougier, 1980). The primary role of the polysaccharide in morphogenesis can be attributed to microfibrillar polymers. During apical elongation, chitin seems to be essential for cross-linking $\beta$-1,3-glucans (Wessels, 1986). The same role may be attributed to cellulose as that during protoplast regeneration of Saprolegnia in which a cellulose network is first deposited around the cells (Girard et al., 1984).

In order to elucidate the role of cellulose we have investigated the effects of Congo red, a dye which interacts with numerous polysaccharides, exhibiting a particularly high affinity for $\beta$-glucans (Wood, 1980; Wood \& Fulcher, 1983). Through hydrogen bonds, Congo red binds to nascent glucan chains and, as a consequence of this interaction, the glucan chains are prevented from crystallizing to form microfibrils. This has been observed using Congo red or calcofluor white in the bacterium Acetobacter xylinum (Benziman et al., 1980; Haigler et al., 1980; Haigler \& Benziman, 1982; Colvin \& Witter, 1983), in algae (Quader, 1981 ; Roberts et al., 1982; Schnepf et al., 1982; Quader et al., 1983), and in the cellular slime mould Polysphondylium pallidum (Choi \& O'Day, 1984). Similar results have been described for the formation of chitin microfibrils in the alga Poterioochromonas stipitata (Herth, 1980), and in the yeasts Saccharomyces cerevisiae (Vannini et al., 1983) and Candida albicans (Elorza et al., 1983; Rico et al., 1985; Roncero \& Duran, 1985). In yeasts, these dyes induce cell wall thickenings and formation of abnormal septa, with a lack of wall crystallinity. In the filamentous fungi Aspergillus niger and Geotrichum lactis the dyes induce abnormal morphogenesis and the hyphal tips burst or expand into swellings (Pancaldi et al., 1984; Roncero \& Duran, 1985).

In this paper we describe the morphological effects of Congo red on the apical growth of S. monoica in relation to the pattern of cell wall synthesis and cellulose structure.

\section{Methods}

Culture methods. The strain Saprolegnia monoica Pringsheim no. 53967 Dick obtained from CBS, Baarn, the Netherlands, was maintained on a wheat flour medium. Fungal colonies were grown at $24^{\circ} \mathrm{C}$ for $16 \mathrm{~h}$ on dialysis membrane over solid medium (Machlis, 1953) by inoculating plugs $(5 \mathrm{~mm}$ diam.) removed from the growing edge of 4-d-old colonies. 

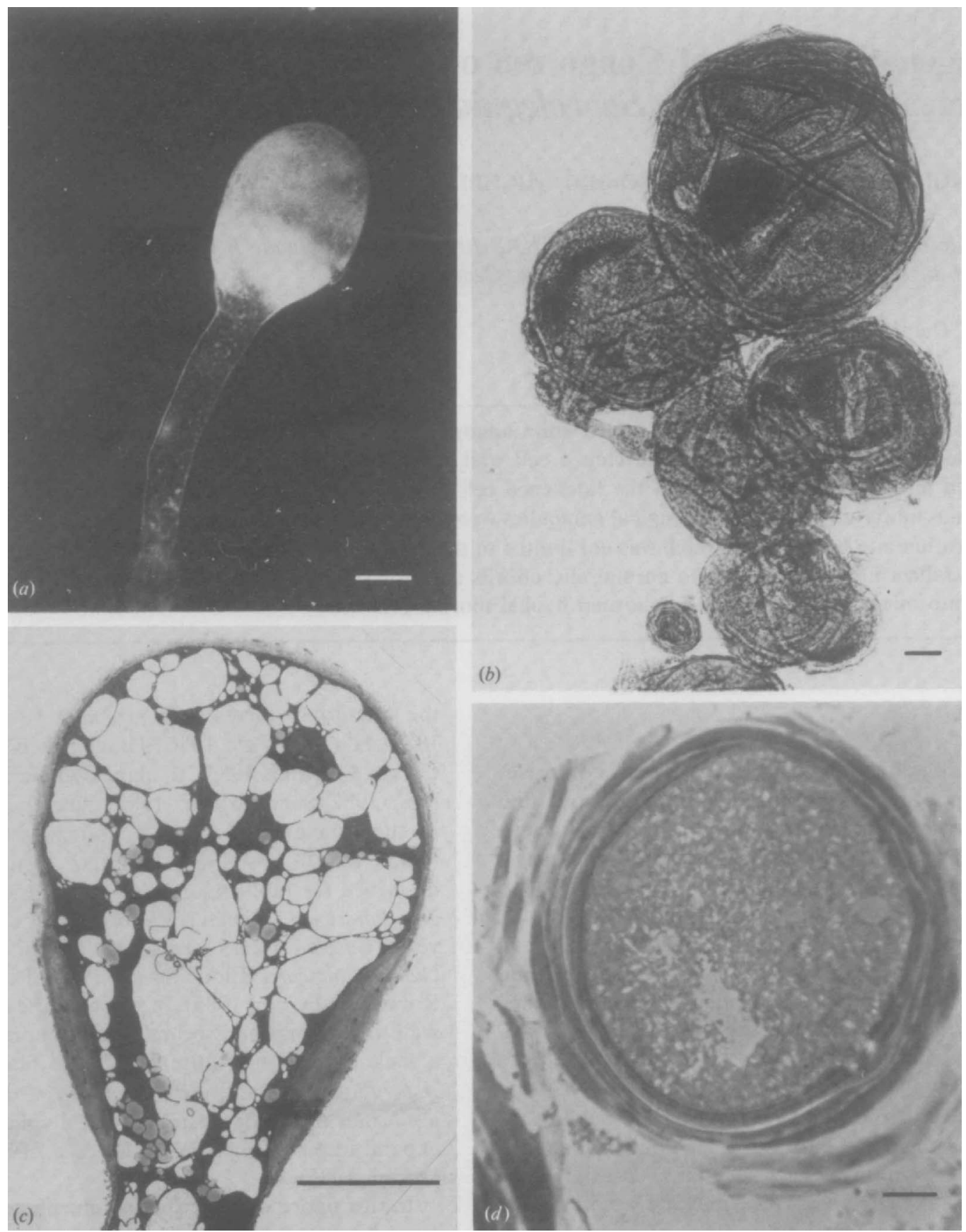

Fig. 1. Light and electron micrographs of hyphae grown in the presence of Congo red. (a,c) After $3 \mathrm{~h}$ growth in the presence of $25 \mu \mathrm{g}$ Congo red $\mathrm{ml}^{-1}$ the hyphal tip was swollen, highly vacuolated, and exhibited cell wall thickenings. $(b, d)$ After $5 \mathrm{~d}$ growth in the presence of $50 \mu \mathrm{g}$ Congo red $\mathrm{ml}^{-1}$ the hyphae presented successive swellings with a cell wall consisting of multilayered thickenings. Bars, $10 \mu \mathrm{m}$.

The effects of Congo red (Serva) were studied on colonies transferred to a liquid medium (Machlis, 1953) containing up to $1000 \mu \mathrm{g}$ Congo red $\mathrm{ml}^{-1}$, and grown for different times. At intervals, colonies were taken for observations or transferred to labelling medium containing radioactive glucose.

Autoradiography. Colonies grown for up to $6 \mathrm{~h}$ in liquid media with or without Congo red were transferred to a liquid medium containing
$30 \mu \mathrm{Ci} \mathrm{ml} l^{-1} \quad\left(1.11 \mathrm{MBq} \mathrm{ml}^{-1}\right) \quad\left[{ }^{3} \mathrm{H}\right] \mathrm{glucose} \quad\left(2.5 \mathrm{mCi} \mathrm{mmol}^{-1}\right.$; 92.5 MBq mmol ${ }^{-1}$ ). After labelling ( 1 to $5 \mathrm{~min}$ ), colonies were rinsed and then fixed in $\mathrm{HCl}(1 \mathrm{M})$ for $30 \mathrm{~min}$. Cytoplasm was dissolved, as described by Bartnicki-Garcia \& Lippman (1969), by heating at $100^{\circ} \mathrm{C}$ in ethanol/1 $\mathrm{M}-\mathrm{NaOH}(2: 1, \mathrm{v} / \mathrm{v})$ for $5 \mathrm{~min}$. Colonies were mounted on slides coated with gelatin and then covered with stripping autoradiographic film (Kodak AR 10). Slides were developed (Kodak D 19) after exposure for several days (usually 7 ). 
Electron microscopy. Fungal colonies grown in liquid medium with or without Congo red were fixed for $2 \mathrm{~h}$ with $3 \%(\mathrm{v} / \mathrm{v})$ glutaraldehyde in sodium cacodylate buffer $(0.1 \mathrm{M}, \mathrm{pH} 7 \cdot 4)$. After three buffer washes, colonies were postfixed with $2 \%$ (w/v) $\mathrm{OsO}_{4}$ for $30 \mathrm{~min}$. After rinsing, colonies were dehydrated in a graded series of increasing ethanol concentrations and embedded in Epon. Thin sections were cut with diamond knives on an ultramicrotome, mounted on Collodion-coated grids, and stained in $2 \%(\mathrm{w} / \mathrm{v})$ aqueous uranyl acetate for $30 \mathrm{~min}$ and in Reynold's lead citrate for $5 \mathrm{~min}$.

In order to visualize cellulose microfibrils, fungal colonies were treated according to Updegraff (1969) by heating at $100^{\circ} \mathrm{C}$ in acetic/nitric acid reagent $(80 \%, \mathrm{v} / \mathrm{v}$, acetic acid/nitric acid, $10: 1, \mathrm{v} / \mathrm{v})$ for $30 \mathrm{~min}$. After rinsing in water, treated colonies were deposited on Collodion-coated grids and then shadowed with $\mathrm{Au} / \mathrm{Pd}$.

Observations and photographs were made by using either Hitachi HU 12 A or Philips EM 300 electron microscopes.

Glucose labelling and fractionation of hyphal cell walls. Colonies were grown for $3 \mathrm{~h}$ in liquid medium with or without $25 \mu \mathrm{g}$ Congo red mil ${ }^{-1}$ and then labelled with $\left[{ }^{14} \mathrm{C}\right]$ glucose $\left(2 \mu \mathrm{Ci} \mathrm{ml}^{-1}, 74 \mathrm{kBq} \mathrm{ml}^{-1}\right)$. After $20 \mathrm{~min}$ labelling, mycelia were washed with water then freeze-dried. After cytoplasm extraction as described above, cell walls were extracted with water at $100^{\circ} \mathrm{C}$ for $15 \mathrm{~min}$, then centrifuged at $2500 \mathrm{~g}$ for $5 \mathrm{~min}$ to collect the hot-water-soluble fraction. The cellulose fraction was isolated according to Updegraff (1969) in acetic/nitric acid reagent for $30 \mathrm{~min}$ in a boiling water bath. Non-hydrolysable material representing the cellulose fraction was collected by centrifugation at $10000 \mathrm{~g}$ for $15 \mathrm{~min}$. Radioactivity was determined by liquid scintillation counting.

\section{Results}

Microscopic observations of $S$. monoica in the presence of Congo red

When actively growing colonies of $S$. monoica, obtained on solid medium, were transferred to a liquid medium containing $100 \mu \mathrm{g}$ Congo red $\mathrm{ml}^{-1}$, hyphal growth was markedly reduced and hyphal morphology was altered. After $24 \mathrm{~h}$ culture, hyphae appeared as a chain of large spherical swellings of diameter 10 to 30 times larger than the normal hyphae width (i.e. 200 to $600 \mu \mathrm{m}$ versus 15 to $20 \mu \mathrm{m})$. Following agitation, these swellings could be detached from the chain leading to isolated spherical structures (Fig. $1 b$ ). When replaced in a normal liquid medium, they were able to generate a normal mycelium indicating that these aberrant structures were viable, corresponding to a non-permanent alteration of the hyphal structure.

In order to obtain information about the sequence of the morphological aberrations induced by the dye, observations were made at regular time intervals, starting from a few minutes after transfer to a medium containing $25 \mu \mathrm{g}$ Congo red $\mathrm{ml}^{-1}$. Hyphal tips were immediately stained a heavy red (Fig. $2 a$ ). After $30 \mathrm{~min}$ exposure to the dye, some hyphal tips began to swell (Figs $1 a, 2 b$ ), and after $3 \mathrm{~h}$ all the tips were converted into spheres (Fig. 2d) while the older parts of hyphae were not deformed. Basal parts of the swellings were

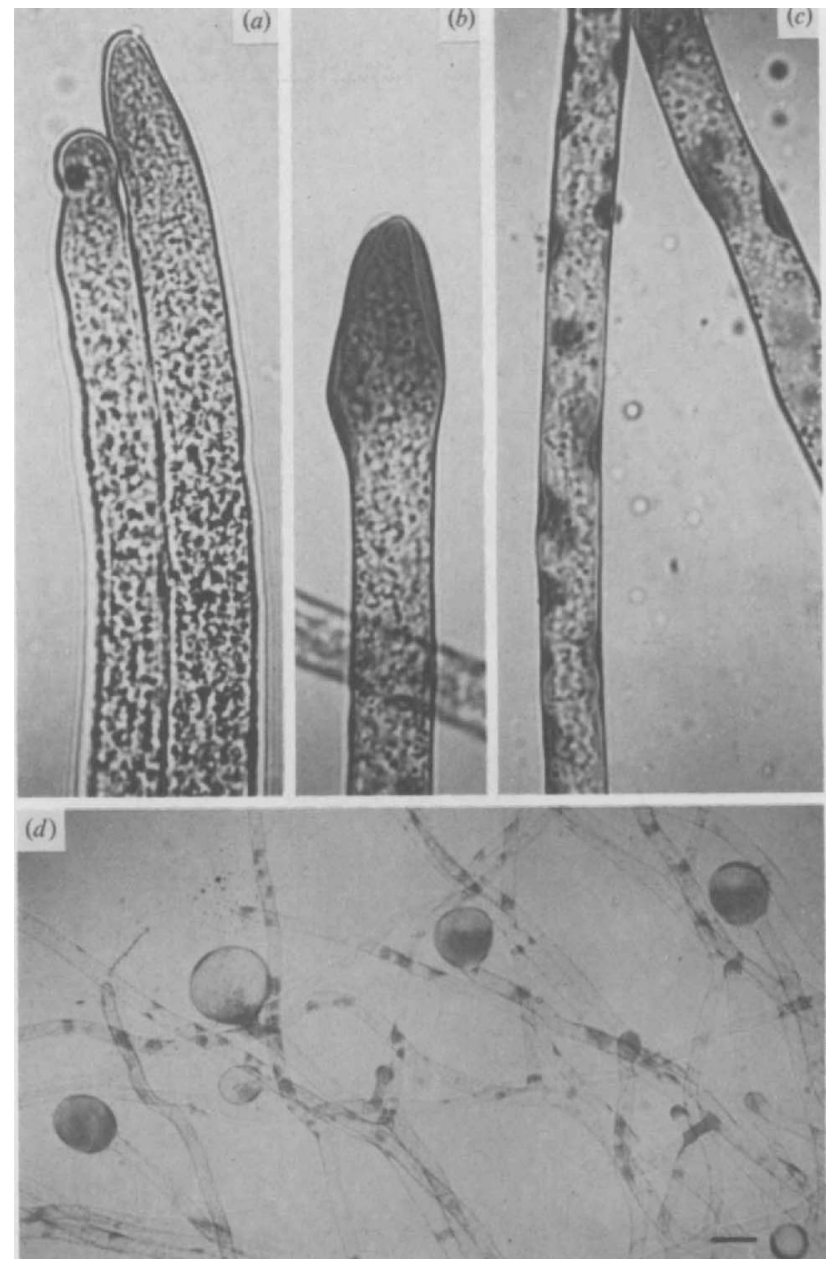

Fig. 2. Light micrographs of hyphae grown in a liquid nutrient medium containing $25 \mu \mathrm{g}$ Congo red $\mathrm{ml}^{-1}$. During the first minutes of incubation $(a)$, the hyphal tips took on a heavy colouration and after $30 \mathrm{~min}(b)$ began to swell. After $3 \mathrm{~h}$ incubation $(c, d)$ the hyphal tips were converted into bulges and coloured cell wall ingrowths were observed along the hyphae. Bar, $50 \mu \mathrm{m}$.

of ten more coloured by the dye than their extremities and the subapical regions of the hyphae. Coloured spots were also observed along subapical parts of the hyphae (Fig. $2 c, d)$. These coloured areas were related to a local cell wall thickening (Fig. $2 b, c$ ).

\section{Autoradiographic study of the morphological alterations induced by Congo red}

Cell wall polymer deposition was studied by following $\left[{ }^{3} \mathrm{H}\right]$ glucose incorporation into cell wall glucans after a 5 min pulse. In controls, glucan deposition was mainly localized at the hyphal tips; decreasing incorporation was observed in the subapical zones corresponding to cell 


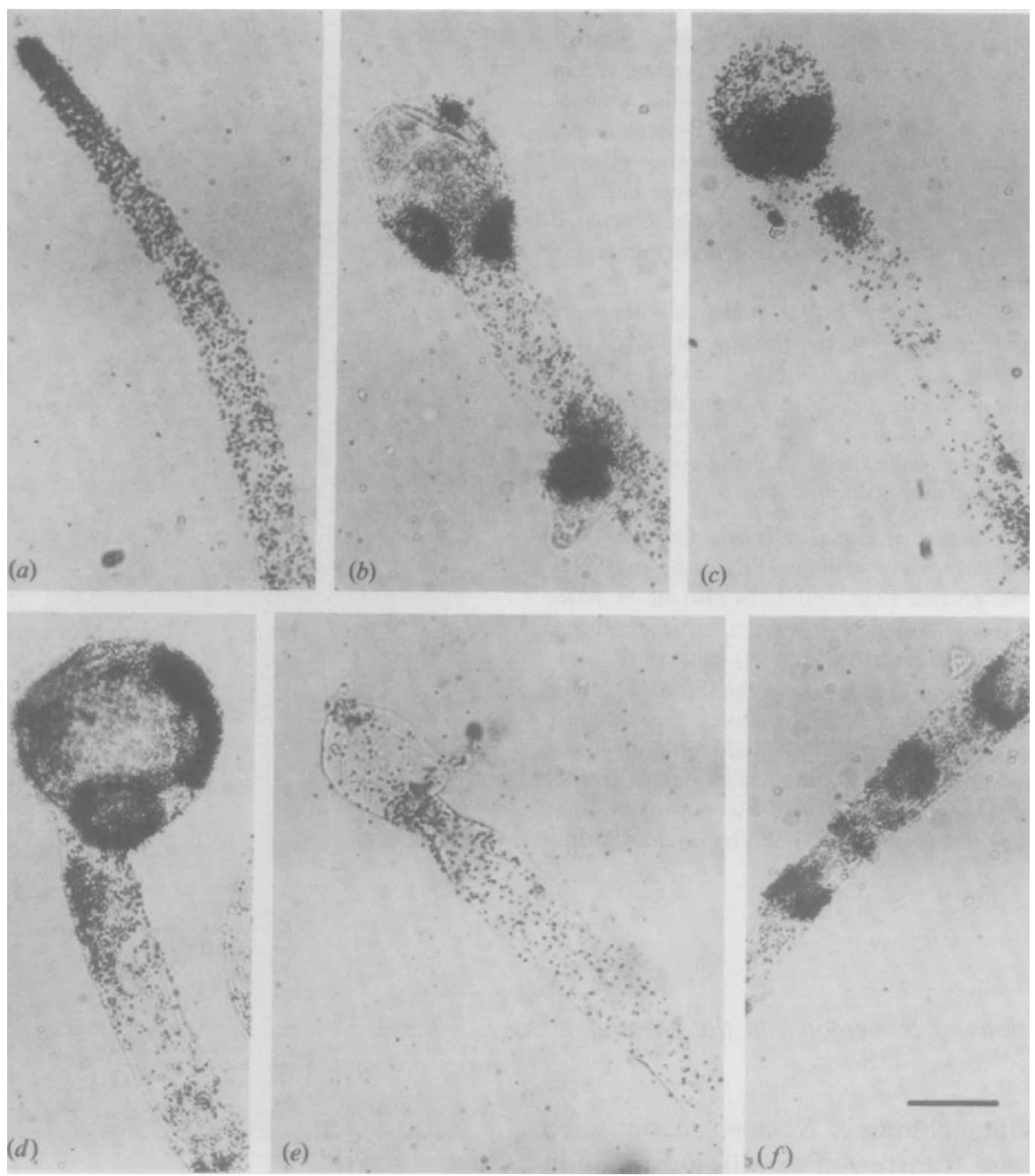

Fig. 3. Light microscopy autoradiography of hyphae labelled with $\left[{ }^{3} \mathrm{H}\right] \mathrm{glucose}\left(30 \mu \mathrm{Ci} \mathrm{ml} \mathrm{m}^{-1}\right)$. (a) Control hyphae incubated for $5 \mathrm{~min}$ in radioactive glucose. $(b, c, d, e)$ Hyphae grown for $3 \mathrm{~h}$ in the presence of $25 \mu \mathrm{g}$ Congo red $\mathrm{ml}^{-1}$ then labelled for 5 min in radioactive glucose. $(f)$ Hyphae incubated for $1 \mathrm{~min}$ with $\left[{ }^{3} \mathrm{H}\right]$ glucose followed by $3 \mathrm{~h}$ growth in the presence of $25 \mu \mathrm{g}$ Congo red $\mathrm{ml}^{-1}$. Bars, $15 \mu \mathrm{m}$.

wall thickening (Fig. $3 a$ ). After $3 \mathrm{~h}$ growth in a medium containing $25 \mu \mathrm{g}$ Congo red $\mathrm{ml}^{-1}$, followed by a $5 \mathrm{~min}$ pulse with radioactive glucose, hyphae exhibited an abnormal pattern of glucose incorporation (Fig. $3 b, c, d$ ). Maximal incorporation was observed in the more heavily stained parts of the hyphae. Labelling localized in the spherical swellings had an irregular distribution and very intense radioactive areas were seen at the base of the swellings and along the hyphae (Fig. 3f). Their localization correlated with the distribution of the heavily stained spots. The very intense labelling observed indicates that Congo red does not inhibit glucan synthesis. Cell wall polymer deposition was uncoordinated and the polarity which characterizes control hyphae was lost during Congo red treatment. In other experiments, fungal colonies were labelled for $1 \mathrm{~min}$ in a control medium then transferred to a Congo red medium. After $3 \mathrm{~h}$ growth in the presence of the dye, colonies were treated for autoradiography. The labelled area which corresponds to the site of cell wall deposition at the hyphal apex before Congo red treatment was observed at the base of the swollen apices (Fig. $3 e$ ). This indicates that the swelling induced by Congo red occurred at the extreme tip of the hyphae. The lateral walls of the apex constituted the base of the swellings. The cell wall thickenings observed in this area may be due to enzymes in the apical region remaining active after Congo red treatment. 


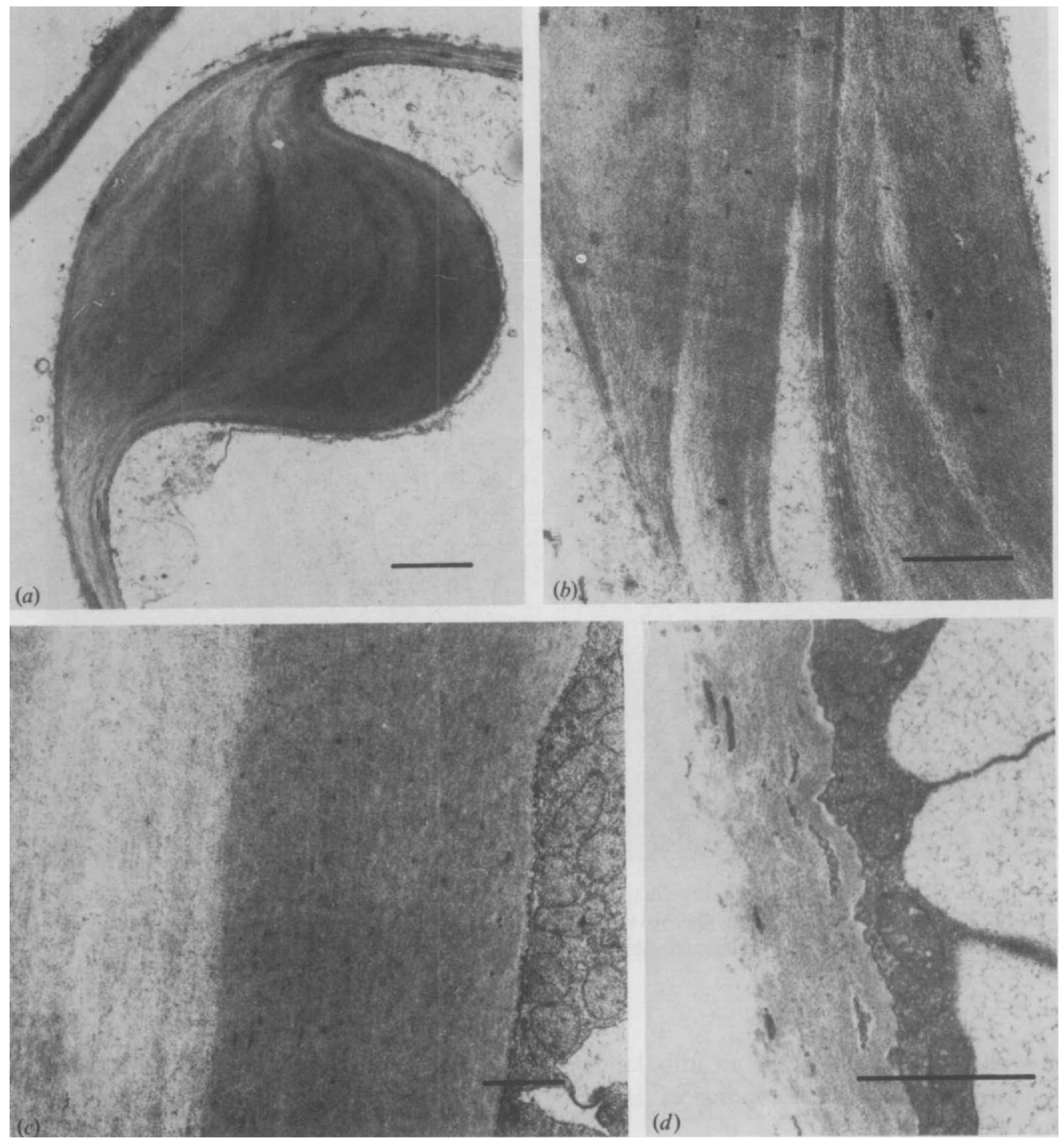

Fig. 4. Electron micrographs of hyphal cell walls of colonies grown in a medium containing $50 \mu \mathrm{g}$ Congo red ml ${ }^{-1}$. (a) Multilayered structure of subapical cell wall ingrowths. (b) Successive layers of homogeneous and reticulate material in the cell wall of apical swellings (see also Fig. $1 b, d) .(c, d)$ Cell wall structure of apical swellings (see also Fig. $1 c, d$ ) made of successive layers and containing entrapped cytoplasmic vesicles. Bars, $1 \mu \mathrm{m}$.

\section{Ultrastructural study of the hyphae grown in the presence of Congo red}

After $3 \mathrm{~h}$ growth in a liquid medium containing $25 \mu \mathrm{g}$ Congo red $\mathrm{ml}^{-1}$, the swollen tips of the hyphae showed a loss of their characteristic polarity. The swellings contained numerous vacuoles of different sizes, which appeared empty (Fig. 1c); nuclei and mitochondria were randomly distributed. The walls of the swelling cells were thicker ( 5 to 6 times as thick in the basal part, twice as thick in the apical part) than in normal hyphae. These thickenings were composed of different layers corres- ponding to alternating clear and opaque zones (Figs $1 c$, $1 d, 2 c, 4 c)$. Isolated swellings produced after $3 \mathrm{~d}$ growth in a Congo red nutritive medium were characterized by very thick cell walls. The cell wall, 20 times thicker than in normal hyphae (i.e. $10 \mu \mathrm{m}$ instead of $0.5 \mu \mathrm{m}$ ) was made of successive layers arranged in scales (Figs $1 d, 2 b$, $4 b$ ). These layers, separated by a reticular material, showed a similar orientation with respect to the plasma membrane. Chains of cytoplasmic microvesicles were seen entrapped between cell wall layers (Fig. $4 d$ ); their origin remained uncertain but could be due to the isolation of cytoplasmic material by the deposition of a 


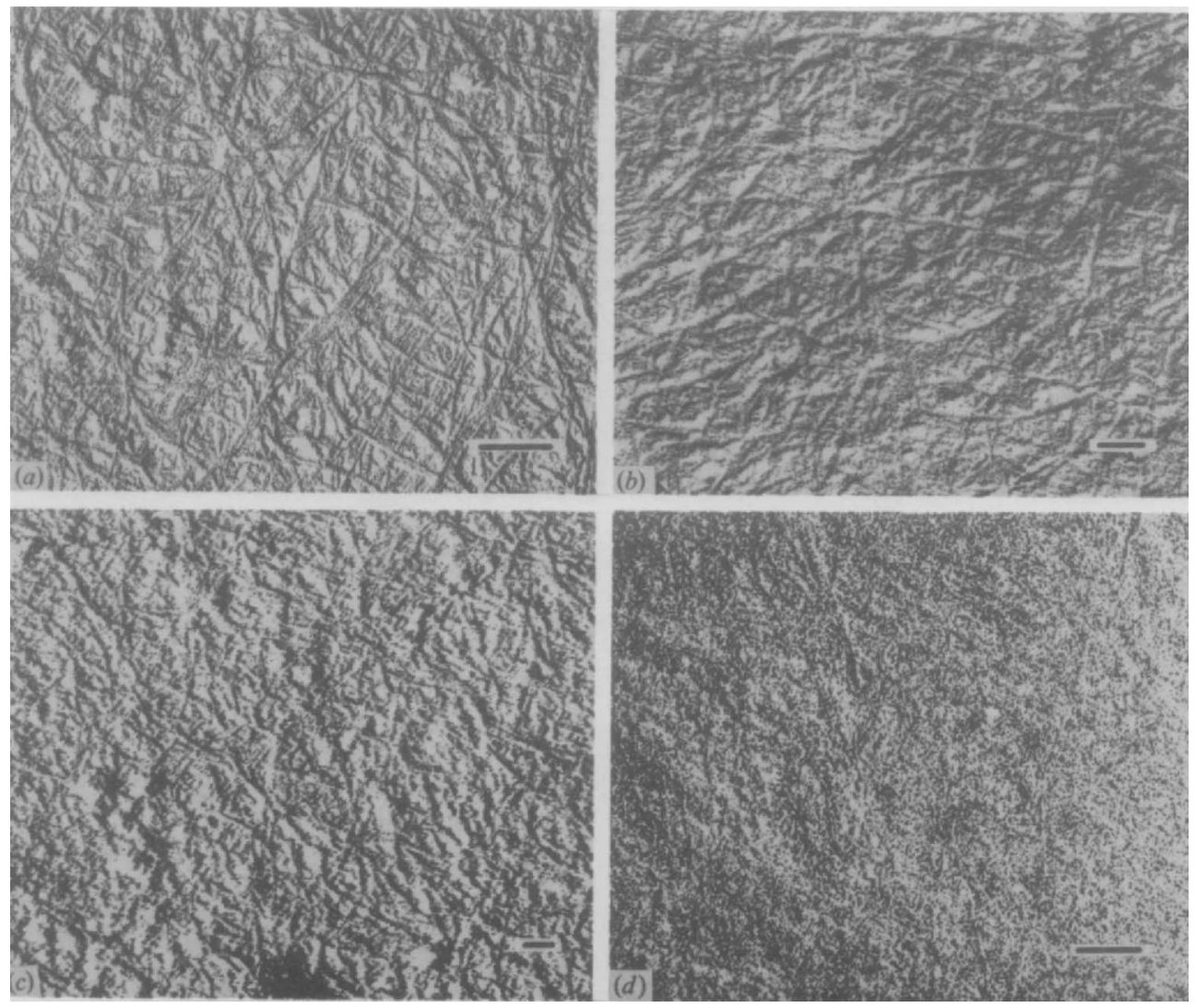

Fig. 5. Shadow-cast preparations of the cell wall cellulose. Cellulose was isolated after extraction of other polysaccharides by acetic/nitric acid $\left(100^{\circ} \mathrm{C}\right.$ for $\left.30 \mathrm{~min}\right)$. In normal hyphae $(a)$ the microfibrillar net of cellulose was clearly visible. In the presence of $50 \mu \mathrm{g}$ Congo red $\mathrm{ml}^{-1}$, cellulose was produced as short microfibrils $(b, c)$ or as amorphous material $(d)$. Bars, $0.5 \mu \mathrm{m}$.

new layer of cell wall material reflecting an imbalance between vesicle fusion and surface expansion as in plasmalemmasome biogenesis.

Cell wall thickenings, observed in subapical zones along the tubular part of the hyphae, were also comprised of successive layers due to a centripetal deposition of cell wall material (Fig. $4 a$ ).

\section{Ultrastructural study of cell wall cellulose}

Fungal colonies, grown in the presence or absence of Congo red, were treated at $100{ }^{\circ} \mathrm{C}$ for $30 \mathrm{~min}$ with acetic/nitric acid reagent in order to remove cell wall glucans other than cellulose. Electron microscopy of shadow-cast hyphal preparations showed that cellulose microfibrils were clearly visible in the cell walls of control colonies (Fig. $5 a$ ). Cell walls synthesized in the presence of Congo red contained a large amount of cellulose present in different states. A network of microfibrils loosely embedded in an amorphous material was observed in the older parts of the hyphae (Fig. $5 b$ ).
In cell wall thickenings, cellulose appeared as very thin and short microfibrils (Fig. 5c) or as an amorphous material with few or no microfibrils (Fig. $5 d$ ).

\section{Effects of Congo red on cell wall synthesis}

As the pattern of cell wall synthesis was modified by Congo red, labelling with radioactive glucose was performed to measure the rate of cellulose synthesis. Following $3 \mathrm{~h}$ growth in the presence of $25 \mu \mathrm{g}$ Congo red $\mathrm{ml}^{-1}$, mycelia were labelled for $20 \mathrm{~min}$ with $2 \mu \mathrm{Ciml}^{-1}$ $\left(74 \mathrm{kBq} \mathrm{ml}^{-1}\right)\left[{ }^{14} \mathrm{C}\right]$ glucose.

The incorporation of the label [measured as c.p.m. (mg freeze-dried mycelium $)^{-1}$ ] into cellulose and different cell wall fractions (i.e. $\beta$-glucans of Congo-red-treated mycelia) was greater than in the control cultures (a typical experiment is presented in Table 1). The increase of cellulose synthesis was 70 and $97 \%$ in two different experiments while incorporation into other fractions was stimulated by 55 and $80 \%$. This indicates that, at low concentrations, Congo red stimulated overall cell wall synthesis. 
Table 1. Effect of Congo red on glucose incorporation into cell wall polysaccharides

After $3 \mathrm{~h}$ growth in the absence or presence of $25 \mu \mathrm{g}$ Congo red $\mathrm{ml}^{-1}$ mycelia were labelled with $2 \mu \mathrm{Ci} \mathrm{m}^{-1}\left(74 \mathrm{kBq} \mathrm{ml}^{-1}\right)$ $\left[{ }^{14} \mathrm{C}\right]$ glucose. After $20 \mathrm{~min}$ labelling, mycelia were washed, freezedried and the cell walls were fractionated as described in Methods. The results are those of a typical experiment done in duplicate. Error was about $10 \%$.

\begin{tabular}{lcc}
\hline \hline & \multicolumn{2}{c}{$\begin{array}{c}\text { Glucose incorporation } \\
\text { [c.p.m. (mg mycelium) }\end{array}$} \\
\cline { 2 - 3 } \multicolumn{1}{c}{ Cell wall } & Control & $\begin{array}{c}\text { Congo-red-treated } \\
\text { mycelia }\end{array}$ \\
\hline fractions & mycelia & 2630 \\
Hot-water soluble & 1590 & 1841 \\
Updegraff soluble* & 1025 & 2453 \\
Updegraff insoluble* & 1242 & \\
(i.e. cellulose) & & \\
\hline \hline
\end{tabular}

* Soluble in acetic/nitric acid reagent (Updegraff, 1969).

\section{Discussion}

Congo red induced spectacular morphological aberrations of hyphal development in S. monoica. Following a short incubation with the dye, hyphal tips became swollen leading to spherical swellings with very thick cell walls at their base. During long periods of culture in the presence of the dye, successive swellings were produced resulting in a hyphal morphology resembling a string of pearls. Similar types of morphological aberrations have been observed in Aspergillus niger and Trichophyton mentaprophytes. These fungi, which have cell walls of chitin, in contrast to the cellulose cell walls of Saprolegnia, develop curled and swollen hyphae in the presence of Congo red (Pancaldi et al., 1985, 1988). However, in $S$. monoica, a complete disorganization of hyphal growth was induced by high Congo red concentrations, the mycelia producing large swellings (up to $1 \mathrm{~mm}$ ) which became detached from old mycelia. These swellings had very thick cell walls comprising stacks of different layers corresponding to successive waves of cell wall polysaccharide synthesis. These abnormal structures were viable, 'germinating' and growing into normal mycelia when inoculated onto the control nutritive medium.

The effect of Congo red on the extension zones of the hyphae was greater than that on older mycelia. The staining of hyphal tips was immediate indicating that cellulose was easily reached by the dye. In contrast, subapical zones were not coloured, probably because cellulose was protected by cross-linkage with other cell wall polysaccharides. Subapical wall ingrowths developing as false septa were heavily stained, indicating that they were composed of cellulose. Similar cellulose structures have also been observed during normal growth of Phytophthora parasitica (Gooday \& Hunsley, 1971).
These morphological aberrations are associated with a loss of polarity, an increase of cell wall polymer deposition and a modification of cellulose structure.

Disturbance of polarity is marked by a random distribution of organelles (mitochondria, nuclei, vacuoles) in the swollen tips. This loss of polarity would affect the membrane flow and, consequently, the delivery of polysaccharide synthases. The disturbance of cytoplasmic streams could stop the movement to the apex of cell wall vesicles formed in the subapical area. These cytoplasmic vesicles could fuse at any place with the plasma membrane creating new sites of cell wall synthesis. These effects could explain the numerous wall ingrowths observed in older zones of hyphal treated with Congo red and the multilamellate structure of thickened cell walls.

Congo red modifies cellulose structure. Cellulose microfibrils were clearly observed in control hyphae, whereas in hyphae treated with Congo red, cellulose was present as an amorphous material or as short microfibrils embedded in amorphous material.

In addition to the morphological changes described, Congo red increased the rate of cell wall polymer synthesis. This stimulation of synthesis of amorphous cellulose by Congo red resembles the effect on cellulose synthesis of Congo red or calcofluor white in other organisms (Haigler et al., 1980; Quader, 1981; Roberts et al., 1982; Schnepf et al., 1982; Choi \& O'Day, 1984; Colvin \& Witter, 1983). Thus in $S$. monoica, as in other organisms, cellulose polymerization and crystallization into microfibrils are two coupled processes, as shown for Acetobacter xylinum (Benziman et al., 1980). This suggests that, in fungi, the mechanism of cellulose synthesis is very similar to that of other organisms. By uncoupling these two processes and preventing cellulose crystallization, Congo red would suppress the rate limiting step in cellulose synthesis, leading to an increase of abnormal cellulose polymerization by enzymes remaining active. This would explain our autoradiography results, which showed that the enzymes localized at the base of the swellings (where cell walls are very thick) corresponded to the enzymes localized at the extremity of the tip before it began to swell. In a normal hypha, as a result of apical growth, the constituents of the apical tip become the constituents of the subapical zones as the hypha elongates, and the enzymes normally active at the tip are inactivated in the subapical zones. In the case of hyphae treated with Congo red, the apical enzymes keep their activity for a longer period; this leads to the formation of the basal cell wall thickenings, made of noncrystalline cellulose, which are observed in the swellings.

An increase of the synthesis of cell wall glucans other than cellulose was also observed. Perhaps Congo red prevents cross-linking of the cell wall polymers through 
binding to cell wall polysaccharides and suppresses a limiting step in synthesis thus leading to an overall increase in cell wall synthesis.

The stimulatory effect of Congo red on cell wall polysaccharide synthesis is probably the result of its direct binding to nascent polymers when they are extruded outside the plasma membrane rather than the result of a direct action on glucan synthases. This confirms the vectorial synthesis of cell wall polysaccharides. In the presence of Congo red, the synthesis of amorphous polysaccharides does not provide a sufficiently rigid structure to contain the internal turgor pressure. In spite of their thickness, the aberrant cell walls are weakened structures which can be deformed. Moreover, Congo red may increase cell wall weakening by coating cellulose and preventing cross-linking of $\beta$ glucans to cellulose, a phenomenon which occurs normally at hyphal tips, consequently bringing cell wall rigidity (Wessels, 1986). The morphological effects of Congo red on $S$. monoica hyphae confirm the primary role of microfibrillar cell wall polysaccharides in hyphal morphogenesis.

\section{References}

Bartnicki-Garcia, S. \& LipPMAN, E. (1969). Fungal morphogenesis: cell wall construction in Mucor rouxii. Science 165, 302-304.

Benziman, M., Haigler, C. H., Brown, R. M., JR, White, A. R. \& COOPER, K. M. (1980). Cellulose biogenesis: polymerization and crystallization are coupled processes in Acetobacter xylinum. Proceedings of the National Academy of Sciences of the United States of America 77, 6678-6682.

BURNETT, J. H. (1979). Aspects of the structure and growth of hyphal walls. In Fungal Walls and Hyphal Growth, pp. 1-25. Edited by J. H. Burnett \& A. P. J. Trinci. Cambridge: Cambridge University Press.

CHOI, A. H. C. \& O'DAY, D. H. (1984). Calcofluor staining of cellulose during microcyst differentiation in wild-type and mutant strains of Polysphondylium pallidum. Journal of Bacteriology 157, 291-296.

Colvin, J. R. \& WITTER, D. E. (1983). Congo red and calcofluor white inhibition of Acetobacter xylinum cell growth and of bacterial cellulose microfibril formation: isolation and properties of a transient, extracellular glucan related to cellulose. Protoplasma 116, $34-40$.

ElORZA, M. V., Rico, H. \& SENTANDREU, R. (1983). Calcofluor white alters the assembly of chitin fibrils in Saccharomyces cerevisiae and Candida albicans cells. Journal of General Microbiology 129. $1577-1582$.

FÈvre, M. \& RougIER, M. (1980). Hyphal morphogenesis of Saprolegnia : cytological and biochemical effects of coumarin and glucono- $\delta$-lactone. Experimental Mycology 4, 343-361.

Girard, V., Capellano, A. \& FÈVre, M. (1984). $\beta$-Glucan synthesis and glucan synthase activities during early stages of cell wall regeneration by protoplasts from Saprolegnia monoica. Journal of General Microbiology 130, 2367-2374.

GoODAY, G. W. \& HUNSLEY, D. (1971). Cellulose wall ingrowths in Phytophthora parasitica. Transactions of the British Mycological Society 57, 178-179.

Haigler, C. H. \& Benziman, M. (1982). Biogenesis of cellulose I microfibrils occurs by cell-directed self-assembly in Acetobacter xylinum. In Cellulose and Other Natural Polymer Systems, pp. 273-295. Edited by R. M. Brown Jr. New York \& London: Plenum Press.

Haigler, C. H., Brown, R. M., JR \& Benzman, M. (1980). Calcofluor white ST alters the in vivo assembly of cellulose microfibrils. Science 210, 903-906.

HERTH, W. (1980). Calcofluor white and Congo red inhibit chitin microfibril assembly of Poterioochromonas: evidence for a gap between polymerization and microfibril formation. Journal of Cell Biology 87, 442-450.

MACHLIS, L. (1953). Growth and nutrition of watermolds in the subgenus Euallomyces. II, Optimal composition of the minimal medium. American Journal of Botany 40, 449-460.

Pancaldi, S., Poli, F., Dall'Olio, G. \& Vannini, G. L. (1984). Morphological anomalies induced by Congo red in Aspergillus niger. Archives of Microbiology 137, 185-187.

Pancaldi, S., Poli, F., Dall'Olio, G. \& Vannini, G. L. (1985). Anomalous morphogenetic events in yeasts exposed to the polysaccharide-binding dye Congo red. Caryologia 38, 247-256.

Pancaldi, S., Poli, F., Dall'Olio, G. \& Vannini, G. L. (1988). Aberrant development of Trichophyton mentagrophytes hyphae cultured in the presence of Congo red. Microbios 54, 81-86.

QUADER, H. (1981). Interruption of cellulose microfibril crystallization. Naturwissenschaften 68, 428-429.

Quader, H., Robinson, D. G. \& van Kempen, R. (1983). Cell wall development in Oocystis solitaria in the presence of polysaccharide binding dyes. Planta 157, 317-323.

Rico, H., Miragall, F. \& Sentandreu, R. (1985). Abnormal formation of Candida albicans walls produced by calcofluor white: an ultrastructural and stereologic study. Experimental Mycology 9 , 241-253.

Roberts, E., Seagull, R. W., Haigler, C. \& Brown, R. M., JR (1982). Alteration of cellulose microfibril formation in eukaryotic cells: Calcofluor white interferes with microfibril assembly and orientation in Oocystis apiculata. Protoplasma 113, 1-9.

RONCERO, C. \& DURAN, A. (1985). Effect of Calcofluor white and Congo red on fungal cell wall morphogenesis: in vivo activation of chitin polymerization. Journal of Bacteriology 163, 1180-1185.

SCHNEPF, E., DEICHGRÄBER, G. \& HERTH, W. (1982). Development of cell wall appendages in Acanthosphaera zachariasi (chlorococcales): kinetics, site of cellulose and microfibril assembly, and barb formation. Protoplasma 110, 203-214.

SIETSMA, J. H. (1969). Protoplast formation and cell wall composition of some Oomycete species. PhD thesis, University of Amsterdam.

UPDEGRAFF, D. M. (1969). Semi-micro determination of cellulose in biological materials. Analytical Biochemistry 32, 420-424.

VANNini, G. L., Poli, F. \& Pancaldi, S. (1983). Effects of Congo red on wall synthesis and morphogenesis in Saccharomyces cerevisiae. Plant Science Letters, 31, 9-17.

Wessels, J. G. H. (1986). Cell wall synthesis in apical hyphal growth. International Review of Cytology 104, 37-39.

WoOD, P. J. (1980). Specificity in the interaction of direct dyes with polysaccharides. Carbohydrate Research 85, 271-287.

WOOD, P. J. \& FulChER, R. G. (1983). A basis for specific detection and histochemistry of polysaccharides. Journal of Histochemistry and Cytochemistry 31, 823-826. 